\title{
Levels of Adherence and Associated Factors Among Children on ART Over Time in Northwest, Ethiopia: Evidence from a Multicenter Follow-Up Study
}

\author{
Fisha GebreEyesus (D) \\ Dagninet Mitku² \\ Tadesse Tarekegn' \\ Bogale Temere' \\ Tamene Terefe' \\ Amsalu Belete ${ }^{2}$ \\ Getasew Legas (iD) ${ }^{2}$ \\ Dejen Feleke $\mathbb{D}^{2}$ \\ Moges Gelaw Taye $\mathbb{D}^{2}$ \\ Nega Baye $\mathbb{I D}^{2}$ \\ Fitalew Admasu (D) ${ }^{2}$ \\ Enyew Dagnew (D) ${ }^{2}$ \\ Tewachew Liyeh ${ }^{2}$ \\ Melkamu Jimma $\mathbb{( D}^{3}$ \\ Ermias Chanie $\mathbb{D}^{2}$ \\ 'Department of Nursing, College of \\ Medicine and Health Sciences, Wolkite \\ University, Wolkite, Ethiopia; \\ ${ }^{2}$ DebreTabor University, DebreTabor, \\ Ethiopia; ${ }^{3}$ Department of Nursing, \\ College of Health Sciences, Assosa \\ University, Assosa, Ethiopia
}

Correspondence: Fisha GebreEyesus Email fishalebel@gmail.com
Background: Despite the increased availability of antiretroviral therapy (ART), its success depends on a high level of adherence to a life-long antiretroviral therapy. However, the extent and factors associated with adherence to ART are not well known, especially in the current study setup. Therefore, this study aimed to assess the level of adherence and associated factors among children on ART in Northwest, Ethiopia.

Methods: A retrospective follow-up study was conducted on human immunodeficiency virus (HIV)-infected children receiving ART at South Gondar public hospitals. Children receiving ART from January 1, 2015, to November 30, 2020, were included in the study. A computer-generated simple random sampling technique was employed. The data were entered into the EpiData version 3.1 and analyzed by STATA 14 statistical software. Bivariable logistic regression was fitted for each predictor variable. Moreover, those variables having a p-value $\leq 0.25$ in bivariate analysis were fitted into a multivariable logistic regression model. P-value $<0.05$ was used to declare significance.

Results: A total of $363 \mathrm{HIV}$-infected children were involved in the study. From $363 \mathrm{HIV}$-infected children, the level of adherence to ART was found to be $78.2 \%, 95 \%$ CI $(73.6,82.2)$. TB coinfection [adjusted odds ratio $(\mathrm{AOR})=3.8,95 \% \mathrm{CI}(1.41,10.1)$ ], short duration on ART $(\mathrm{AOR}=$ 3.4, 95\% CI $(1.60,7.20))$, treatment failure $(\mathrm{AOR}=10.2,95 \% \mathrm{CI}(3.95,26.2))$, and Zidovudine containing ART regimen $(\mathrm{AOR}=3.5,95 \% \mathrm{CI}(1.1,10.9))$ were significant predictors of poor adherence.

Conclusion: The current study showed that the level of adherence to ART was found to be low TB co-infection, short duration of ART, Zidovudine-containing ART regimen, and treatment failure were found to be significantly associated with poor adherence. Further studies on adherence rate and its determinants with multiple adherence measurements using prospective and multicenter studies were recommended.

Keywords: adherence, ART, children, Ethiopia

\section{Background}

Human Immunodeficiency Virus (HIV) is an RNA virus that causes Acquired Immune Deficiency Syndrome (AIDS), ${ }^{1}$ which remains the leading cause of morbidity and mortality throughout the world. ${ }^{2}$ Globally, 37.7 million people were living with HIV in 2020, 1.5 million new HIV infections, and 680.000 AIDS-related deaths. $^{3}$ Of this, HIV infection among children constitutes $4.5 \%$ of people living with HIV and $6.87 \%$ of total HIV/AIDS deaths. ${ }^{3}$

About $50 \%$ of children living with HIV/AIDS die before the age of 2 years as a result of recurrent opportunistic infections such as pneumonia, diarrhea, 
malnutrition, and malaria. ${ }^{4}$ According to the Summary of the global HIV epidemic (2019), Africa contributes $67.6 \%$ of the total HIV-infected people and $63.7 \%$ of the total HIV/AIDS deaths. ${ }^{5}$

As one of the African countries, the case in Ethiopia is not different. In 2016, there were 62.000 children aged $<15$ years living with HIV, 3800 newly diagnosed cases, and 2.900 deaths. $^{6}$ The introduction of effective antiretroviral (ART) treatment in the 1990s drastically reduced AIDS-related mortality and morbidity. ${ }^{7}$ Ethiopia was among the first African countries to introduce ART in 2003 in selected health facilities following the issuance of the National Antiretroviral drugs (ARVS) supply and use policy in $2002 .^{8}$

Antiretroviral therapy (ART) is a treatment for HIV that combines different types of antiretroviral medications, which should be taken throughout life to increase the length and quality of life for people living with HIV by reduction of the viral load and increase of the level of CD 4 cells. ${ }^{9}$ The major factor determining the success of HAART is sustainable and optimum adherence to therapy ${ }^{10}$ as poor adherence increases the risk of virologic failure, viral resistance, and dangerous outcomes such as substance abuse, depression, and spread of infections such as hepatitis. ${ }^{1-14}$ Any patient who misses more than 3 dosages in a one-month treatment course is considered to have achieved suboptimal adherence which is less than $95 \% .^{15}$

Despite the increased availability of ART, implementation among children 0-14 years faces major challenges due to poor adherence. ${ }^{16,17}$ Factors associated with pediatrics ART adherence can be related to caregivers, children themselves, ${ }^{14,18-23}$ socioeconomic, ${ }^{18,19}$ socio-demographic, and socio-cultural factors, ${ }^{24,25}$ or service delivery issues, ${ }^{18,19}$ It is also affected by high pill burden, poor palatability, long-term toxicity, ${ }^{26,27}$ side effects of ARVs, ${ }^{24-27}$ ART regimes, ${ }^{14,18-21,25}$ drug dosing. ${ }^{24,25}$ Duration on ART, ${ }^{28}$ the health of the child, ${ }^{29}$ child knowledge of their HIV status, ${ }^{30}$ and psychosocial factors ${ }^{17}$ have also been associated with pediatric ART adherence Unlike adults, young children rely upon their caregivers for their medicines. ${ }^{18}$ Moreover, the experience of HIV-related rejections, non-acceptance, stigma, and discrimination minimize the patients' desire to maintain their optimal levels of health. ${ }^{14}$

The level of adherence to ART among HIV-infected children varied from $49 \%$ to $100 \%$ globally. ${ }^{22}$ Similarly, in Ethiopia, it varied from $34.8 \%^{31}$ to $95.5 \%^{32}$ in Tikur
Anbessa and Debre Birhan Referral Hospitals, respectively.

Ethiopia has adopted the 2014 UNAIDS 90-90-90 (90\% of PLHIV know their status, $90 \%$ of PLHIV who know their status are on treatment (ART) and 90\% of PLHIV on treatment have attained viral suppression by 2020) strategy. $^{33}$ However, only $79-71-87 \%$ have been achieved in 2018. ${ }^{34}$ Although Ethiopia has been working a lot to attain the strategy since adherence is taken a lion's share to achieve the goal, poor level of adherence was greatly challenged especially in the study area.

Moreover, the risk factors of poor adherence were varied across the countries and the regions. Fortunately, most of the risk factors of poor adherence to ART are modifiable. Result determining the risk factors of poor adherence is a crucial role for intervention to reduce its magnitude and associated complication in the study area. As a result, this study aimed to determine the level of adherence to ART and its associated factors among children receiving ART at South Gondar public Hospitals, 2020 .

\section{Materials and Methods \\ Study Settings and Subjects}

A retrospective follow-up study was conducted on HIVinfected children receiving ART at South Gondar public Hospitals. Children receiving ART from January 1, 2015, to November 30, 2020, were included. South Gondar public hospitals are found in Debre Tabor town which is the capital of South Gondar Zone in Amhara Regional State, Northwest Ethiopia. Debre Tabor Town is located 667 and $102 \mathrm{~km}$ far from Addis Ababa and Bahir Dar, respectively. ${ }^{35}$

South Gondar public hospital contained 05 hospitals that provide pediatric ART services. These hospitals are Debre Tabor compressive specialized hospital, Nefas Mewucha District Hospital, Mekane Eyesus District Hospital, Addis Zemen District Hospital, and Andabet District Hospital. As per the 2020 report, the total of HIVinfected children was 1312. The hospitals have a total of 71 Health care providers working at ART.

\section{Source Populations}

All HIV-positive children less than 15 years who had been taking ARV and were on follow-up from January 1, 2015, to November 30, 2020, at selected South Gondar public hospitals were the source population. 


\section{Study Population}

Sampled children less than 15 years who had been taking ARV medications and were on following- from January 1, 2015, to November 30, 2020, at selected South Gondar public hospitals were the study population.

\section{Inclusion Criteria}

Children of less than 15 years who had been taking ART for a minimum of one month were included.

\section{Exclusion Criteria}

Participants who had incomplete data (that means charts without outcome variables and major explanatory variables) were excluded.

\section{Sample Size Determination and Sampling Procedure}

The sample size was calculated by using STATA 14 software of the two-population proportion formula taking the assumptions - $95 \%$ confidence level, $80 \%$ optimum statistical power, and taking type one error 5\%. Taking male as exposure group from a previous study conducted in Mekelle Hospital, Ethiopia ${ }^{36}$ denoted by q1 (0.82.0) and female non exposed group denoted by q0 (0.92.6), and then the total sample size, after adding $10 \%$ as incomplete or inconsistent data, will be 381 . The hospitals were categorized into referral and district strata. Then, from the district hospitals stratum, Nefas Mewucha and Mekan Eyesus district Hospitals were selected randomly. From the referral hospital stratum, Debre Tabor specialized compressive specialized hospital was selected since it is the only specialized hospital in South Gondar Zone. Then, the sample size was allocated proportionally for each hospital. A simple random sampling technique was employed through a computer-generated system by taking the ART registration logbook as a sampling frame (Figure 1).

\section{Operational Definitions}

Poor adherence was defined as the percentage of drug dosage calculated from the total monthly doses of ART drugs $<85 \%{ }^{37}$

A CD4 count: CD4 below the threshold level was classified based on the age of the child (i.e infants $\mathrm{CD} 4<1500 / \mathrm{mm}^{3}, 12-35$ months $<750 / \mathrm{mm}^{3}, 36-59$ months $<350 / \mathrm{mm}^{3}$ and $\geq 5$ years $\left.<200 / \mathrm{mm}^{3}\right) .{ }^{38}$

Anemia was defined as having a hemoglobin level $<10 \mathrm{mg} / \mathrm{dl}^{39}$
Underweight or stunting was defined as weight for age $Z$-score $<-2$ SD for under-five children and BMI for age Z-score $<-2 \mathrm{SD}$ for older children. ${ }^{40}$

\section{Data Collection Procedures}

Data were collected using a pretested data abstraction format prepared from the national ART guidelines and by reviewing different kinds of literature. The abstraction tool was designed to collect information including sociodemographic, clinical, and treatment-related characteristics. The data were collected by three BSc nurses and supervised by two MSC pediatrics nurses. The training was given to data collectors and supervisors. The pre-test was done on 5\% of the sample size in Addis Zemen district Hospital which is 57 kilometers away from Debre Tabor Town and one of the district hospitals in South Gondar.

\section{Data Processing and Analysis}

The data were entered into the EpiData version 3.1 and analyzed by STATA 14 statistical software.

Descriptive and summary statistics are explored through the table and figures. Finally, the outcome level adherence to ART was dichotomized into good or poor.

The bivariable logistic regression model was fitted for each predictor variable. Moreover, those variables having a p-value $\leq 0.25$ in bivariate analysis were fitted into a multivariable logistic regression model. Adjusted odds ratios with $95 \%$ confidence interval and $p$-values were used to measure the strength of association and to identify statistically significant predictors. In multivariable analysis variables having $\mathrm{P}$-value $<, 0.05$ were considered as significant predictors of poor adherence. The multicollinearity assumption was checked using the standard error and correlation matrix. Besides, Hosmer-Lemeshow statistics and Omnibus tests were performed, and HosmerLemeshow's test was found to be insignificant ( $p$-value = 0.483). While Omnibus tests were significant $(p \leq 0.01)$ indicating the model was fitted.

\section{Results}

\section{Socio-Demographic Characteristics of the Study Participants}

A total of 381 medical records were reviewed among which 18 had incomplete data were excluded. Thus, a total of 363 children were included in the analysis which makes a completeness rate of $95.3 \%$. The mean 


\section{All Pediatric ART services hospital in South Gondar zone}

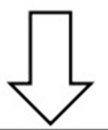

1.Debre Tabor comphesive specialized hospital 2. Nefas Mewucha District Hospital 3. Mekane Eyesus District Hospital 4. Addis zemen District Hospital 5. Andabet District Hospital

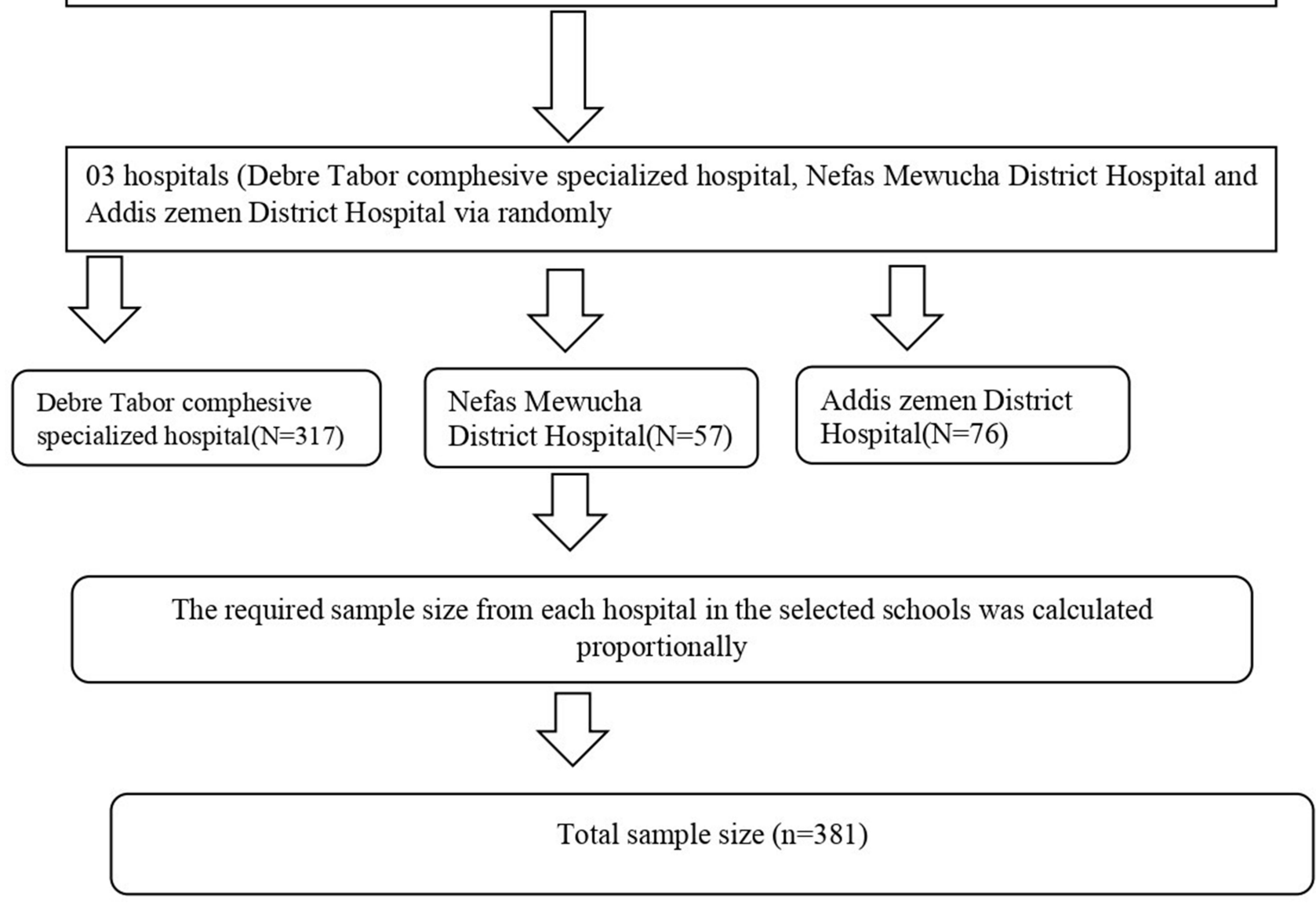

Figure I Schematic presentation of the recruitment and allocation process for adherence to antiretroviral among children receiving ART at South Gondar public Hospitals, Northwest, 2020.

age of the study participants was $7.34( \pm 3.4 \mathrm{SD})$ years, and $196(54.0 \%)$ of them were in the age group of 5-9 years. Nearly half of $186(51.2 \%)$ were males and $184(50.7 \%)$ of children know their HIV status. Besides, $243(66.9 \%)$ of caregivers were married and $52(41.9 \%)$ cannot read and write whereas 99 (27.3\%) had completed secondary school (Table 1).

\section{Clinical and Treatment-Related}

\section{Characteristics of Children on ART}

Of 363 HIV-infected children, 186 (51.2\%) were underweight, and 263 (72.5\%) were WHO stage (I and II).
Seventy-one (19.6.3\%) and 36 (9.9\%) of study participants had a CD4 count below the threshold of and treatment failure, respectively. The majority $(81.0 \%, \mathrm{n}=294)$ were on CPT users whereas 253 (69.7\%) did not take IPT. Fiftynine $(16.3 \%)$ and $41(11.3 \%)$ of the participants had anemia $(<10 \mathrm{gm} / \mathrm{dL})$ and $\mathrm{TB}$, respectively. Two hundred forty $(56.3 \%)$ of the study participants were on the Zidovudine-containing regimen and 231 (63.6\%) were initiated ART before 2014. Regarding the duration of ART, 167 (46.0\%) of study participants were taking ART $>59$ months (Table 2). Finally, 79 (21.8\%) of the study participants had poor adherence (Figure 2). 
Table I Socio-Demographic Characteristics of Children Receiving ART at South Gondar Public Hospitals, Northwest, $2020(n=363)$

\begin{tabular}{|c|c|c|c|}
\hline Variable & Categories & Number & Percent \\
\hline $\begin{array}{l}\text { Age of the child } \\
\text { (years) }\end{array}$ & $\begin{array}{l}0-4 \\
5-9 \\
10-14\end{array}$ & $\begin{array}{l}109 \\
196 \\
58\end{array}$ & $\begin{array}{l}30.0 \\
54.0 \\
16.0\end{array}$ \\
\hline Sex & $\begin{array}{l}\text { Male } \\
\text { Female }\end{array}$ & $\begin{array}{l}186 \\
177\end{array}$ & $\begin{array}{l}51.2 \\
48.8\end{array}$ \\
\hline Residence & $\begin{array}{l}\text { Rural } \\
\text { Urban }\end{array}$ & $\begin{array}{l}73 \\
290\end{array}$ & $\begin{array}{l}20.1 \\
79.9\end{array}$ \\
\hline $\begin{array}{l}\text { Marital status of } \\
\text { caregivers }\end{array}$ & $\begin{array}{l}\text { Single } \\
\text { Married } \\
\text { Widowed/ } \\
\text { Divorced }\end{array}$ & $\begin{array}{l}49 \\
243 \\
71\end{array}$ & $\begin{array}{l}13.5 \\
66.9 \\
19.6\end{array}$ \\
\hline $\begin{array}{l}\text { Caregiver's } \\
\text { educational status }\end{array}$ & $\begin{array}{l}\text { Cannot read and } \\
\text { write } \\
\text { Primary school } \\
(1-8) \\
\text { Secondary school } \\
(9-12)\end{array}$ & $\begin{array}{l}152 \\
92 \\
99\end{array}$ & $\begin{array}{r}41.9 \\
25.3 \\
27.3\end{array}$ \\
\hline HIV disclosure Status & $\begin{array}{l}\text { Yes } \\
\text { No }\end{array}$ & $\begin{array}{l}184 \\
179\end{array}$ & $\begin{array}{l}50.7 \\
49.3\end{array}$ \\
\hline
\end{tabular}

\section{Factors Associated with Poor Adherence to ART}

In the bivariable logistic regression analysis residence, weight for height, hemoglobin level, WHO stages, CD4 counts, regimen type, cotrimoxazole preventive therapy (CPT), treatment failure, TB status, and duration on ART having $\mathrm{P}$ value less than 0.25 and fitted into a multivariable logistic regression model. In the multivariable model zidovudine regimen contained at baseline, presence treatment failure, presence of TB co-infection, and duration on ART $<36$ months were predictors of poor adherence.

The odds of children who were enrolled in zidovudinecontaining ART regimen were $(\mathrm{AOR}=3.5,95 \% \mathrm{CI}: 1.1$ 10.9) three folds more likely to be poor adherent than their counterparts. The odds of being poor adherence among HIV-positive children on ART who had TB was around four higher than those who had no TB 3.8 (1.41-10.1) $(\mathrm{OR}=3.8,1.41-10.1)$. The odds of children on ART with treatment failure was around 10 times higher to be poor adherence than those who had no treatment failure (AOR= 10.2, 3.95-26.2); similarly, HIV-positive children on ART with $<36$ months on ART [OR $=3.4(95 \%$ CI: $1.60,7.20)$ ]
Table 2 Clinical Characteristics of Study Participants Receiving ART at South Gondar Public Hospitals, Northwest, $2020(n=363)$

\begin{tabular}{|c|c|c|c|}
\hline Variable & Categories & Number & Percent \\
\hline Weight for height & $\begin{array}{l}\text { Normal } \\
\text { Underweight }\end{array}$ & $\begin{array}{l}177 \\
186\end{array}$ & $\begin{array}{l}48.8 \\
51.2\end{array}$ \\
\hline Hgb level & $\begin{array}{l}<10 \mathrm{mg} / \mathrm{dl} \\
>10 \mathrm{mg} / \mathrm{dl}\end{array}$ & $\begin{array}{l}59 \\
304\end{array}$ & $\begin{array}{l}16.3 \\
83.7\end{array}$ \\
\hline WHO stage & b2.5 & & 263 \\
\hline III \&IV & 100 & 27.5 & \\
\hline CD4 counts or \% & $\begin{array}{l}\text { Below threshold } \\
\text { Above threshold }\end{array}$ & $\begin{array}{l}71 \\
292\end{array}$ & $\begin{array}{l}19.6 \\
80.4\end{array}$ \\
\hline Regimen at baseline & $\begin{array}{l}\text { Zidovudine } \\
\text { contains } \\
\text { Non-zidovudine } \\
\text { contains }\end{array}$ & $\begin{array}{l}314 \\
49\end{array}$ & $\begin{array}{l}86.5 \\
13.5\end{array}$ \\
\hline $\begin{array}{l}\text { Cotrimoxazole } \\
\text { preventive therapy } \\
\text { (CPT) }\end{array}$ & $\begin{array}{l}\text { Yes } \\
\text { No }\end{array}$ & $\begin{array}{l}69 \\
294\end{array}$ & $\begin{array}{l}19.0 \\
81.0\end{array}$ \\
\hline $\begin{array}{l}\text { Isoniazid preventive } \\
\text { therapy (IPT) }\end{array}$ & $\begin{array}{l}\text { No } \\
\text { Yes }\end{array}$ & $\begin{array}{l}253 \\
110\end{array}$ & $\begin{array}{l}69.7 \\
30.3\end{array}$ \\
\hline Treatment failure & $\begin{array}{l}\text { Yes } \\
\text { No }\end{array}$ & $\begin{array}{l}36 \\
327\end{array}$ & $\begin{array}{l}9.9 \\
90.1\end{array}$ \\
\hline TB status & $\begin{array}{l}\text { Yes } \\
\text { No }\end{array}$ & $\begin{array}{l}41 \\
322\end{array}$ & $\begin{array}{l}11.3 \\
88.7\end{array}$ \\
\hline Year initiation & $\begin{array}{l}<2014 \\
\geq 2014\end{array}$ & $\begin{array}{l}231 \\
132\end{array}$ & $\begin{array}{l}63.6 \\
36.4\end{array}$ \\
\hline Duration on ART & $\begin{array}{l}<36 \text { months } \\
36-59 \text { months } \\
>59 \text { moths }\end{array}$ & $\begin{array}{l}129 \\
67 \\
167\end{array}$ & $\begin{array}{l}35.5 \\
18.5 \\
46.0\end{array}$ \\
\hline $\begin{array}{l}\text { Follow-up status of } \\
\text { Adherence }\end{array}$ & $\begin{array}{l}\text { Good } \\
\text { Poor }\end{array}$ & $\begin{array}{l}284 \\
79\end{array}$ & $\begin{array}{l}78.2 \\
21.8\end{array}$ \\
\hline
\end{tabular}

were more likely to poorly adhere to their ART $>59$ months in the follow-up period (Table 3).

\section{Discussion}

This study revealed that the level of adherence to ART in south Gonder public hospitals was found to be $78.9 \%$. Besides, TB co-infection, short duration of ART, Zidovudine containing ART regimen, and treatment failure were found to be significantly associated with poor adherence.

The finding is comparable with the study conducted in Ethiopia (78.6\%), Uganda (79\%), Nigeria (76.1\%), and Myanmar (76.2\%). ${ }^{41-44}$ However, this finding is higher than the studies conducted at Tikur Anbessa Hospital 


\section{Levels of adherence of children receiving ART at South Gondar public Hospitals, Northwest, 2020}

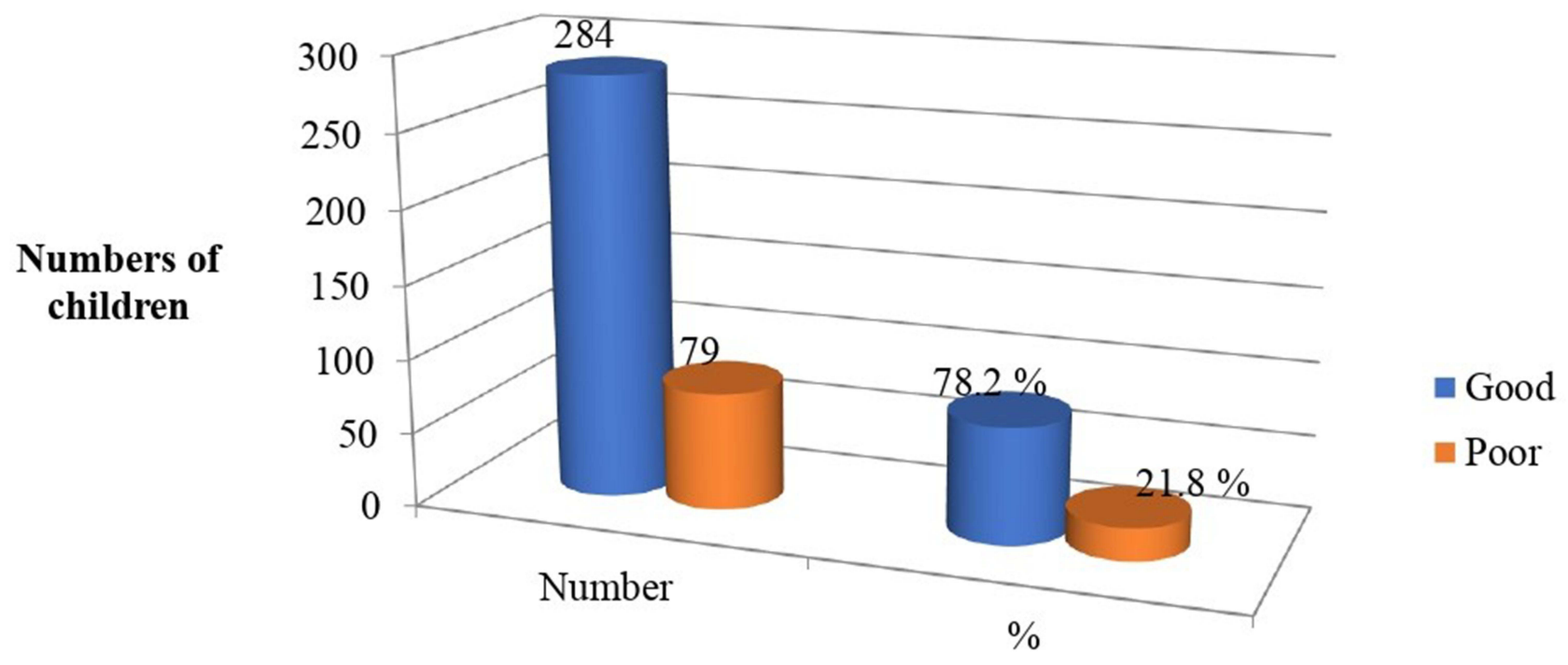

\section{Levels of Adherence}

Figure 2 Levels of adherence of children receiving ART at South Gondar public Hospitals, Northwest, 2020.

(34.8\%) and Jimma (63.8\%). ${ }^{31,45}$ Moreover, the level of adherence to ART is also higher than the studies conducted in Peru (41.7\%), and Brazil (71.6\%). ${ }^{46,47}$ On the other hand, this finding is lower than the studies conducted in Debre Birhan (95.5\%) and Nepal (87.4\%). ${ }^{32,48}$

The discrepancy could be explained by the difference in diagnostic procedures of adherence to ART. In addition, under-reporting due to shortage of skills of healthcare providers or caregivers is usually encounter in lowincome countries than in middle countries. Socioeconomic status, the study design, methods of adherence assessment, sample size, and setting difference are also considered for this variation.

This study showed that children having TB/HIV coinfection increase the level of poor adherence by 3.80 times than children without $\mathrm{TB}$ co-infection $(\mathrm{AOR}=3.80,95 \% \mathrm{CI}$ $(1.41,10.1))$ which is in line with other studies. ${ }^{43,47}$ This might be due to the summative effect of suffering from two chronic conditions, associated with stigma and discrimination that require clinical management for an entire life. In addition to this, medication for confection, treatment, and ART together can contribute to increased pill burden, drugdrug interactions, and more adverse drug effects, all of which are capable of hindering adherence to antiretroviral drugs.
This finding also showed that HIV-positive children on ART with $<36$ months on ART [AOR $=3.4$ (95\% CI: 1.60 , 7.20)] were more likely to be poor adherents than children who were on ART > 59 months in the follow-up period Similar findings were reported from Tanzania ${ }^{49}$ and Nepal. ${ }^{48}$ The duration of treatment prolongs, quality of life improves which in turn motivates the children to have good adherence and to follow every instruction and recommendation provided by the health care providers and caregivers.

The odds of children on ART with treatment failure was around 10 times higher to be poor adherent than those who had no treatment failure $(\mathrm{AOR}=10.2,3.95-26.2)$. This is a similar report from a study conducted in South Africa. ${ }^{50}$

Treatment failure is the main cause of death, drug adaptability, and the development of drug-resistant viral strains which is potentiating challenge globally by reducing drug adherence. Furthermore, HIV drug resistance occurs when mutations develop frequently because of poor adherence (treatment interruptions, inadequate drug concentrations, or/and use of suboptimal drug combinations). ${ }^{50,51}$ Besides, Poor adherence to ART is a major factor of treatment failure, the emergence of drugresistant viruses, disease progression, hospitalization, mortality, and health care costs. ${ }^{52}$ 
Table 3 Bivariable and Multivariable Logistic Regression Analysis on Levels of Adherence Among Children Receiving ART at South Gondar Public Hospitals, Northwest, 2020 (n=363)

\begin{tabular}{|c|c|c|c|c|c|}
\hline \multirow[t]{2}{*}{ Variable } & \multirow[t]{2}{*}{ Categories } & \multicolumn{2}{|c|}{ Level of Adherence } & \multirow[t]{2}{*}{ COR,95\% Cl } & \multirow[t]{2}{*}{ AOR, $95 \% \mathrm{Cl}$} \\
\hline & & Poor (79) & Good (284) & & \\
\hline \multirow[t]{3}{*}{ Age of the child (years) } & $0-4$ & 23 & 86 & $0.8(0.36-1.62)$ & - \\
\hline & $5-9$ & 41 & 155 & $0.8(0.38-1.50)$ & - \\
\hline & $10-14$ & 15 & 43 & 1 & - \\
\hline \multirow[t]{2}{*}{ Sex } & Male & 42 & 144 & I.I (0.67-I.82) & - \\
\hline & Female & 37 & 140 & 1 & - \\
\hline \multirow[t]{2}{*}{ Residence } & Rural & 28 & 45 & $2.9(1.70-5.11)^{*}$ & $3.3(0.96-7.25)$ \\
\hline & Urban & 51 & 239 & 1 & 1 \\
\hline \multirow[t]{3}{*}{ Marital status } & Single & 8 & 41 & $0.6(0.24-1.58)$ & - \\
\hline & Married & 54 & 189 & $0.9(0.49-1.69)$ & - \\
\hline & Widowed/Divorced & 17 & 54 & 1 & - \\
\hline \multirow[t]{3}{*}{ Educational status } & Cannot read and write & 40 & 112 & $1.9(0.97-3.53)$ & $0.7(0.25-2.02)$ \\
\hline & Primary school (I-8) & 22 & 70 & $1.6(0.79-3.34)$ & $0.6(0.18-1.73)$ \\
\hline & Secondary school (9-12) & 16 & 83 & 1 & 1 \\
\hline \multirow[t]{2}{*}{ HIV disclosure Status } & Yes & 48 & 131 & $1.8(1.1-3.00)^{*}$ & $0.7(0.35-1.33)$ \\
\hline & No & 31 & 153 & 1 & I \\
\hline \multirow[t]{2}{*}{ Weight for height } & Normal & 25 & 152 & 1 & 1 \\
\hline & Underweight & 54 & 132 & $2.5(1.46-4.22)^{*}$ & $1.3(0.66-2.61)$ \\
\hline \multirow[t]{2}{*}{ Hgb level } & $<10 \mathrm{mg} / \mathrm{dl}$ & 21 & 38 & $2.3(1.28-4.29)^{*}$ & $1.6(0.68-3.7 I)$ \\
\hline & $>10 \mathrm{mg} / \mathrm{dl}$ & 58 & 246 & I & 1 \\
\hline \multirow[t]{2}{*}{ CD4 counts or $\%$} & Below threshold & 22 & 49 & $1.9(1.04-3.31)^{*}$ & $1.4(0.64-2.94)$ \\
\hline & Above threshold & 57 & 235 & 1 & 1 \\
\hline \multirow[t]{2}{*}{ WHO stages } & $|\&| \mid$ & 39 & 224 & 1 & 1 \\
\hline & III \&IV & 40 & 60 & $3.8(2.26-6.47)^{*}$ & $1.9(0.85-4.10)$ \\
\hline \multirow[t]{2}{*}{ Regimen at baseline } & Zidovudine contain & 73 & 241 & $2.2(0.89-5.30)$ & $3.5(1.1-10.9)^{* *}$ \\
\hline & Non-zidovudine contains & 6 & 43 & 1 & 1 \\
\hline \multirow[t]{2}{*}{ CPT } & Yes & 60 & 234 & 1 & 1 \\
\hline & No & 19 & 50 & $\mathrm{I} .5(0.8 \mathrm{I}-2.70)$ & $1.0(0.42-2.12)$ \\
\hline \multirow[t]{2}{*}{ IPT } & Yes & 21 & 89 & 1 & - \\
\hline & No & 58 & 195 & I.3 (0.72-2.20) & - \\
\hline \multirow[t]{2}{*}{ Treatment failure } & Yes & 21 & 15 & $6.5(3.16-13.4)^{*}$ & $10.2(3.95-26.2)^{* *}$ \\
\hline & No & 58 & 269 & 1 & 1 \\
\hline \multirow[t]{2}{*}{ TB status } & Yes & 24 & 17 & $6.9(3.45-13.6)^{*}$ & $3.8(1.4 I-10.1)^{* *}$ \\
\hline & No & 55 & 55 & 1 & 1 \\
\hline \multirow[t]{2}{*}{ Year initiation } & $<2014$ & 50 & 181 & $0.9(0.58-1.65)$ & - \\
\hline & $\geq 2014$ & 29 & 103 & & - \\
\hline \multirow[t]{3}{*}{ Duration on ART } & $<36$ months & 48 & 81 & $4.1(2.31-7.36)^{*}$ & $3.4(1.60-7.20)^{* *}$ \\
\hline & 36-59 months & 10 & 57 & $1.2(0.54-2.75)$ & $1.6(0.60-4.10)$ \\
\hline & $>59$ moths & 21 & 146 & $\mathrm{I}$ & 1 \\
\hline
\end{tabular}

Notes: ${ }^{*} p$ value $<0.05$ at bivariable logistic regression: ${ }^{* *} p$ value $<0.05$ at multivariable logistic regression. 
In the current study, the odds of children who were enrolled in the Zidovudine-containing ART regimen were (AOR $=3.5,95 \%$ CI: 1.1-10.9) three folds more likely to be poor adherents than their counterparts. This was also supported by the study conducted in Kenya. ${ }^{53}$ The reason behind this might be that those who were on the Zidovudine regiment were more prone to severe life-threatening anemia, severe gastro-intestinal intolerance, fatigue, congestive heart failure, and sepsis/infection which leads to poor treatment adherence. However, inconsistent with studies from Oromia Ethiopia $^{54}$ that showed that receiving protease inhibitors were more likely to be poor adherent. Since ART drugs most likely need to be administered throughout the patient's life, a regimen should be chosen after considering the patient's characteristics, the results of viral drug resistance testing, drug efficacy, and ease of administration, potential AEs, pill size, and dosing frequency.

\section{Limitation of the Study}

While this study is multi-setting, the data on adherence were collected from a chart that was recorded according to the patient's self-report of the amount of medication taken between visits without a standardized set of questions. Being retrospective may also limit the study to evaluate the predictor's variable of adherence to ART includes caregiver's socioeconomic status.

\section{Conclusion}

The current study showed that the level of adherence to antiretroviral therapy was found to be low. TB co-infection, short duration of ART, Zidovudine-containing ART regimen, and treatment failure were found to be significantly associated with poor adherence. Based on our results, health care providers should provide intensive and ongoing counseling to a child and/or their caregivers before and throughout ART, training sessions are required to gain knowledge on disseminating information appropriate to a patient's level of understanding. It will empower patients with correct knowledge about good adherence practice. Despite the earlier presentation of children to care should be motivated, more targeted adherence support should be planned for those who present at an early stage of their illness. Besides this, children or their caretakers should be provided with adequate counseling during medication change or when new medication with a different role is added and establish a system of linkage with other units in the Hospital. For instance, in the case of TB co-infection, they should be linked with the TB unit and the children should take Anti-TB medication with ART drugs. The hospital management team is also expected to provide training on ART adherence counseling to health care providers. Moreover, further studies should be conducted to evaluate and improve the quality of ART service in south Gondar public Hospitals.

\section{Abbreviations}

AIDS, Acquired Immune Deficiency Syndrome; AOR, Adjusted Odds ratio; ART, Anti-Retroviral Therapy; CPT, Cotrimoxazole Preventive Therapy; HIV, Human Immunodeficiency Virus; IPT, Isoniazid Preventive Therapy; TB, Tuberculosis; WHO, World Health Organization.

\section{Ethical Approval and Participant Consent}

Ethical clearance letter was obtained from an ethical review board of Debre Tabor University. In addition, a permission letter was also obtained from each south Gondar public hospital. Since we used secondary data, we did not get informed consent from the study participants. Confidentiality was secured. This study was conducted in accordance with the Declaration of Helsinki.

\section{Acknowledgments}

We would like to thank the Debre Tabor university administrative bodies and south Gondar public hospitals. Moreover, our thanks also go to all individuals who participated in data collection and supervision.

\section{Author Contributions}

All authors made a significant contribution to the work reported, whether that is in the conception, study design, execution, acquisition of data, analysis, and interpretation, or in all these areas; took part in drafting, revising, or critically reviewing the article; gave final approval of the version to be published; have agreed on the journal to which the article has been submitted, and agree to be accountable for all aspects of the work. All authors read and approved the final manuscript.

\section{Disclosure}

The authors report no conflicts of interest in this work.

\section{References}

1. Harrison's Principles of Internal Medicine. 20e | accessMedicine | mcGraw-Hill Medical [Internet]; [cited March 25, 2021]. Available from: https://accessmedicine.mhmedical.com/book.aspx?bookID= 2129. Accessed August 2, 2021. 
2. UNAIDS DATA 2017 [Internet]. [cited March 25, 2021]. Available from: https://www.unaids.org/en/resources/documents/2017/2017 data_book. Accessed August 2, 2021.

3. summary-of-the-global-hiv-epidemic-2020.png $(936 \times 662)$ [Internet]. [cited July 21, 2021]. Available from: https://www.who.int/images/ default-source/departments/hiv/summary-of-the-global-hiv-epidemic -2020.png?sfvrsn=73ac5b6a_5. Accessed August 2, 2021.

4. World Health Organization. Towards the Elimination of Mother-ToChild Transmission of HIV: Report of a Technical Consultation. Geneva Switz: Rep Tech Consult; 2010.

5. Global HIV statistics 2019 pdf - google search [internet]. [cited July 21, 2021]. Available from: https://www.google.com/search? sx srf $=A$ LeKk $01-z j G w v G h n A Y n 7 w K v F h v 5$ VA a Y Y y Q $: 1626846819421 \& q=$ Global + HIV + statistics $+2019+$ pdf\&sa $=$ X\&ved $=$ 2ahUKEwjjx5nWvPPxAhUScBQKHenCDkEQ1QIwE3oECCIQAQ. Accessed August 2, 2021.

6. World Health Organization. Ethiopia, HIV Country Profile: Spectrum Estimates (UNAIDS/WHO) and WHO HIV Country Intelligence Tool. Glob AIDS Monit UNAIDSWHOUNICEF; 2017.

7. Martelli G, Antonucci R, Mukurasi A, Zepherine H, Nöstlinger C, Chemin I. Adherence to antiretroviral treatment among children and adolescents in Tanzania: comparison between pill count and viral load outcomes in a rural context of Mwanza region. PLoS One 2019;14(3):e0214014. doi:10.1371/journal.pone.0214014

8. Ethiopia F. National Guidelines for Comprehensive HIV Prevention, Care, and Treatment. AAMo Health; 2017.

9. Rosen S, Fox MP, Gill CJ, Sepulveda-Amor J. Patient retention in antiretroviral therapy programs in Sub-Saharan Africa: a systematic review. PLOS Med. 2007;4(10):e298. doi:10.1371/journal.pmed.0040298

10. Starace F, Massa A, Amico KR, Fisher JD. Adherence to antiretroviral therapy: an empirical test of the information-motivationbehavioral skills model. Health Psychol. 2006;25(2):153-162. doi:10.1037/0278-6133.25.2.153

11. Nischal KC, Khopkar U, Saple DG. Improving adherence to antiretroviral therapy. Indian $J$ Dermatol Venereol Leprol. 2005;71 (5):316-320. doi:10.4103/0378-6323.16780

12. Zoufaly A, Fillekes Q, Hammerl R, et al. Prevalence and determinants of virological failure in HIV-infected children on antiretroviral therapy in rural Cameroon: a cross-sectional study. Antivir Ther. 2013;18(5):681-690. doi:10.3851/IMP2562

13. Abaasa AM, Todd J, Ekoru K, et al. Good adherence to HAART and improved survival in a community HIV/ AIDS treatment and care program: the experience of The AIDS Support Organization (TASO), Kampala, Uganda. BMC Health Serv Res. 2008;8:241. doi:10.1186/ 1472-6963-8-241

14. Morowatisharifabad MA, Movahed E, Farokhzadian J, et al. Antiretroviral therapy adherence and its determinant factors among people living with HIV/AIDS: a case study in Iran. BMC Res Notes. 2019;12(1):162. doi:10.1186/s13104-019-4204-5

15. Heyer A, Ogunbanjo GA. Adherence to HIV antiretroviral therapy part 11: which interventions are effective in improving adherence? $S A$ Fam Pr. 2006;48:6-10. doi:10.1080/20786204.2006.10873455

16. Marhefka SL, Tepper VJ, Farley JJ, Sleasman JW, Mellins CA. Brief report: assessing adherence to pediatric antiretroviral regimens using the 24-hour recall interview. J Pediatr Psychol. 2006;31(9):989-994. doi:10.1093/jpepsy/jsj107

17. Biadgilign S, Deribew A, Amberbir A, Deribe K. Adherence to highly active antiretroviral therapy and its correlates among HIV infected pediatric patients in Ethiopia. BMC Pediatr. 2008;8(1):53. doi:10.1186/1471-2431-8-53

18. Prendergast A, Tudor-Williams G, Jeena P, Burchett S, Goulder P. International perspectives, progress, and future challenges of pediatric HIV infection. Lancet. 2007;370(958):68-80.

19. Haberer J, Mellins C. Pediatric adherence to HIV antiretroviral therapy. Curr HIVAIDS Rep. 2009;6(4):194-200. doi:10.1007/ s11904-009-0026-8
20. World Health Organization. Antiretroviral Therapy of HIV Infection in Infants and Children: Towards Universal Access. Switzerland: WHO; 2006.

21. Ministry of health of Ethiopia and federal HIV/AIDS prevention and control office: guidel pediatr HIVAIDS care treat Ethiop Addis Ababa; 2008.

22. Vreeman RC, Wiehe SE, Pearce EC, Nyandiko WM. A systematic review of pediatric adherence to antiretroviral therapy in low- and middle-income countries. Pediatr Infect Dis J. 2008;27(8):686-691. doi:10.1097/INF.0b013e31816dd325

23. Simoni JM, Montgomery A, Martin E, New M, Demas PA, Rana S. Adherence to antiretroviral therapy for pediatric HIV infection: a qualitative systematic review with recommendations for research and clinical management. Pediatrics. 2007;119(6):e1371-e1383. doi:10.1542/peds.2006-1232

24. Ingersoll KS, Cohen J. The impact of medication regimen factors on adherence to chronic treatment: a review of the literature. J Behav Med. 2008;31(3):213-224. doi:10.1007/s10865-007-9147-y

25. Paterson DL, Swindells S, Mohr J, et al. Adherence to protease inhibitor therapy and outcomes in patients with HIV infection. Ann Intern Med. 2000;133(1):21-30. doi:10.7326/0003-4819-133-1-200007040-00004

26. World Health Organization. Underlying Causes of Child Death. Geneva, Switzerland: CHERG/WHO; 2011.

27. World Health Organisation (WHO). United Nations Programme on AIDS Progress Report: Glob HIVAIDS Response. Geneva, Switzerland: WHO; 2011.

28. Nozaki I, Dube C, Kakimoto K, Yamada N, Simpungwe JB. Social factors affecting ART adherence in rural settings in Zambia. AIDS Care. 2011;23(7):831-838. doi:10.1080/09540121.2010.542121

29. Williams PL, Storm D, Montepiedra G, Nichols S, Kammerer B, Siros PA. Predictors of adherence to antiretroviral medications in children and adolescents with HIV infection. Pediatrics. 2006;118 (6):e1745-e1757. doi:10.1542/peds.2006-0493

30. Davies M-A, Boulle A, Fakir T, Nuttall J, Eley B. Adherence to antiretroviral therapy in young children in Cape Town, South Africa, measured by medication return and caregiver self-report: a prospective cohort study. BMC Pediatr. 2008;8(1):34. doi:10.1186/1471-2431-8-34

31. Biressaw S, Abegaz WE, Abebe M, Taye WA, Belay M. Adherence to antiretroviral therapy and associated factors among HIV infected children in Ethiopia: unannounced home-based pill count versus caregivers' report. BMC Pediatr. 2013;13:132. doi:10.1186/1471-2431-13-132

32. Ketema AK, Shewangizaw Weret Z. Assessment of adherence to highly active antiretroviral therapy and associated factors among people living with HIV at Debrebrihan referral hospital and Health Center, Northeast Ethiopia: a cross-sectional study. HIV AIDS (Auckl). 2015;7:75-81.

33. Jamieson D, Kellerman SE. The 909090 strategies to end the HIV pandemic by 2030: can the supply chain handle it? J Int AIDS Soc. 2016;19(1):20917. doi:10.7448/IAS.19.1.20917

34. Federal HIV/AIDS prevention and control office: HIV prevention in Ethiopia national road map 2018-2020; November, 2018.

35. Debre Tabor. In: Wikipedia [internet]; 2020 [cited December 31, 2020]. Available from: https://en.wikipedia.org/w/index.php?title= Debre_Tabor\&oldid=972443023. Accessed August 2, 2021.

36. Gultie T. Factors affecting adherence to pediatrics antiretroviral therapy in Mekelle hospital, Tigray Ethiopia. Int J Public Health Sci. 2015;4(1):6.

37. Okechukwu AA, Okechukwu OI. The clinical correlate of tuberculosis in HIV co-infected children at the University of Abuja teaching hospital, Gwagwalada, Nigeria. Niger J Clin Pract. 2011;14 (2):206-211. doi:10.4103/1119-3077.84018

38. Atalell KA, Birhan Tebeje N, Ekubagewargies DT, Yotebieng M. Survival and predictors of mortality among children co-infected with tuberculosis and human immunodeficiency virus at University of Gondar comprehensive specialized hospital, Northwest Ethiopia. A retrospective follow-up study. PLoS One. 2018;13(5):e0197145. doi:10.1371/journal.pone.0197145 
39. Melkamu MW, Gebeyehu MT, Afenigus AD, et al. Incidence of common opportunistic infections among HIV-infected children on ART at Debre Markos referral hospital, Northwest Ethiopia: a retrospective cohort study. BMC Infect Dis. 2020;20(1):50. doi:10.1186/s12879-020-4772-y

40. Refera H, Wencheko E. Survival of HIV-TB co-infected adult patients under ART in Ambo Referral Hospital, Ethiopia. Ethiop $J$ Health Dev. 2013;27(2):88-93.

41. Arage G, Tessema GA, Kassa H. Adherence to antiretroviral therapy and its associated factors among children at South Wollo Zone Hospitals, Northeast Ethiopia: a cross-sectional study. BMC Public Health. 2014;14(1):365. doi:10.1186/14712458-14-365

42. Wadunde I, Tuhebwe D, Ediau M, Okure G, Mpimbaza A, Wanyenze RK. Factors associated with adherence to antiretroviral therapy among HIV infected children in Kabale district, Uganda: a cross-sectional study. BMC Res Notes. 2018;11(1):466. doi:10.1186/ s13104-018-3575-3

43. Ugwu R, Eneh A. Factors influencing adherence to pediatric antiretroviral therapy in Portharcourt, South-South Nigeria. Pan Afr Med J. 2013;16:30. doi:10.11604/pamj.20 13.16.30.1877

44. Thandar M, Mon AS, Boonyaleepun S, Laohasiriwong W. Antiretroviral treatment adherence and associated factors among people living with HIV in a developing country, Myanmar. Int J Community Med Public Health. 2017;3(5):13 18-1325.

45. Abera A, Fenti B, Tesfaye T, Balcha F. Factors influencing adherence to antiretroviral therapy among people living with HIV/AIDS at ART clinic in Jimma University teaching hospital, Southwest Ethiopia. J Pharma Rep. 2015;1(101):2.

46. Soares RD, Brito AM, Lima K, Lapa TM. Adherence to antiretroviral therapy among people living with HIV/AIDS in northeastern Brazil: a cross-sectional study. Sao Paulo Med J. 2019;137(6):479-485. doi:10.1590/1516-3180.2019.0212170919
47. Leyva-Moral JM, Loayza-Enriquez BK, Palmieri PA, et al. Adherence to antiretroviral therapy and the associated factors among people living with HIV/AIDS in Northern Peru: a cross-sectional study. AIDS Res Ther. 2019;16(1):22. doi:10.1186/ s12981-019-0238-y

48. Neupane S, Dhungana GP, Ghimire HC. Adherence to antiretroviral treatment and associated factors among people living with HIV and AIDS in CHITWAN, Nepal. BMC Public Health. 2019;19(1):720. doi:10.1186/s12889-019-7051-3

49. Nyogea D, Mtenga S, Henning L, et al. Determinants of antiretroviral adherence among HIV-positive children and teenagers in rural Tanzania: a mixed-methods study. BMC Infect Dis. 2015;15(1):28. doi:10.1186/s12879-015-0753-y

50. Yassin S, Gebretekle GB. Magnitude and predictors of antiretroviral treatment failure among HIV-infected children in Fiche and Kuyu hospitals, Oromia region, Ethiopia: a retrospective cohort study. Pharmacol Res Perspect. 2017;5(1):e00296. doi:10.1002/prp2.296

51. Endalamaw A, Mekonnen M, Geremew D, Yehualashet FA, Tesera H, Habtewold TD. HIV/AIDS treatment failure and associated factors in Ethiopia: a meta-analysis. BMC Public Health. 2020;20 (1):82. doi:10.1186/s12889-020-8160-8

52. Nachega JB, Marconi VC, van Zyl GU, et al. HIV treatment adherence, drug resistance, virologic failure: evolving concepts. Infect Disord Drug Targets. 2011;11(2):167-174. doi:10.2174/187152611795589663

53. Ochieng W, Kitawi RC, Nzomo TJ, et al. Implementation and operational research: correlates of adherence and treatment failure among Kenyan patients on long-term highly active antiretroviral therapy. J Acquir Immune Defic Syndr. 2015;69(2):e49-e56. doi:10.1097/ QAI.0000000000000580

54. Biru M, Jerene D, Lundqvist P, Molla M, Abebe W, Hallström I. Caregiver-reported antiretroviral therapy non-adherence during the first week and after a month of treatment initiation among children diagnosed with HIV in Ethiopia. AIDS Care. 2017;29(4):436-440. doi: $10.1080 / 09540121.2016 .1257098$
HIV/AIDS - Research and Palliative Care

\section{Publish your work in this journal}

HIV/AIDS - Research and Palliative Care is an international, peerreviewed open-access journal focusing on advances in research in HIV, its clinical progression and management options including antiviral treatment, palliative care and public healthcare policies to control viral spread. The manuscript management system is completely online and includes a very quick and fair peer-review system, which is all easy to use. Visit http://www.dovepress.com/testimonials.php to read real quotes from published authors. 